\title{
Effects of malaria infection in Anopheles stephensi mosquitoes on passage through a wide-mesh net*
}

\author{
Takeshi Kurihara, ${ }^{* *}$ Tetsushi KikUGhI ${ }^{* *}$ and Kazuyo IGhimori ${ }^{* *}$ \\ Department of Medical Zoology, Teikyo University School of Medicine, \\ Itabashi-ku, Tokyo 173, Japan
}

(Received: December 6, 1990)

Key words: Plasmodium yoelii nigeriensis, Anopheles stephensi, infected mosquitoes, reduced activity, cage test, wide-mesh net.

\begin{abstract}
The effects of Plasmodium infection upon the behaviour of vector mosquitoes were examined by the cage-test method. Anopheles stephensi parasitized with Plasmodium yoelii nigeriensis had reduced ability to pass the wide-mesh net barrier. The reduction was particularly remarkable when there was no air-flow in the test cages. It is suspected that in some of these mosquitoes the receptor for chemicals from a blood source may malfunction under a windless condition.
\end{abstract}

The effects of Plasmodium infection upon the behaviour and other life functions of mosquito vectors have been the subject of intensive studies in recent years. Gad et al. (1979) reported that the mortality of Anopheles stephensi infected with $P$. beghei was higher than in normal blood-fed mosquitoes. Klein et al. (1982, 1986) also found a deterioration effect on the longevity of $A n$. dirus infected with $P$. cynomolgi. The reduction of flight activity of $A n$. stephensi was reported when these mosquitoes were parasitized with $P$. cynomolgi (Schiefer et al., 1977) and with $P$. yoelii (Rowland and Boersma, 1988). Rossignol et al. (1984, 1986) found that P. gallinaceum sporozoiteinfected Aedes aegypti were impaired in locating blood vessels but the biting rate was greater than noninfected mosquitoes.

The present paper describes the results of tests of the ability of $A n$. stephensi to pass a barrier after parasitization with $P$. yoelii

* This work was supported in part by a grant from Sumitomo Chemical Co. Ltd.

** 栗原 毅, 菊池哲志, 一盛和世：帝京大学医学部 医動物学教室（干173 東京都板橋区加賀 2-11-1） nigeriensis. The method, called the "cagetest," utilizes a wide-mesh net and cages and, as reported earlier, is useful in determining the behavioural responses of mosquitoes when faced with a physical barrier, or with insecticides (Kurihara et al., 1985, 1987). The same apparatus was adopted to examine the influence of malaria parasites on mosquito behaviour, particularly when on their way to access a blood source.

\section{Materials and Methods}

The mosquitoes used were the BEECH strain of $A n$. stephensi. These were maintained and examined in an insectarium at 23-25 ${ }^{\circ} \mathrm{C}, 80 \% \mathrm{RH}$, and with 16:8 (hr. L:D) photoperiod. Adult mosquitoes were reared in a $30 \times 30 \times 30 \mathrm{~cm}$ cage on a $10 \%$ sucrose solution. $P$. yoelii nigeriensis $\mathrm{N} 67$ strain was preserved in liquid nitrogen. To infect $A n$. stephensi with the parasite, white mice were infected with $10^{7}$ parasitized erythrocytes. Other details on the mosquitoes and parasites were as previously described by one of the authors (Ichimori, 1989). Three days after inoculation, an infected mouse was chosen 
for the mosquitoes to feed on, thereby being the source of infection.

A batch of mosquitoes of both sexes emerging on the same day was kept in a cage for 5 days to allow time for mating. They were then divided into two groups. Approximately 300 females of group A were exposed to a 6-8 week old mouse which had a parasitaemia of 5-20\% and gametocytaemia of 0.01$1 \%$ in 10,000 red blood cells. These mosquitoes engorged with infected blood were separated and allowed to lay eggs on Day 5 after feeding, and then served for the cagetest at 3 p.m. of Day 10. Group B fed on unparasitized (=non-infected) mice were simultaneously treated in the same manner as a noninfected control group.

The cage-test apparatus was composed of two wire cages $(30 \times 30 \times 30 \mathrm{~cm})$, each with two round holes, and a piece of wide-mesh net. The cages were placed side by side with a net stretched between the two holes. One cage served as a release cage containing 20-25 hungry mosquitoes of either group A or $\mathrm{B}$, and the other as a bait cage containing a mouse. Mosquitoes were able to pass through the netting easily and feed on the bait animal if the mesh size was greater than $6 \mathrm{~mm}$ (Kurihara et al., 1989).

After release, the mosquitoes were left overnight and were recovered from each cage at 10 a.m., and the number of living and dead, fed or unfed, was recorded. Live insects were immediately dissected to determine the number of oocysts present.

Each experiment had 3-4 replications, and a total of 13 experiments was carried out through 4 series or for 4 batches of mosquitoes. The percentage of oocysts present $(=\%$ infected) was similar in each series, ranging from $40-65 \%$. The first and second series were compared for their ability to pass through the nets of different size mesh. In the first series, test cages were placed so that they were exposed to an intermittent side flow of air from the room air-conditioning. In the second series the cages were placed so that the direction of air-flow was from bait to release cage and velocity of the air-flow was measured at $0.15 \mathrm{~m} / \mathrm{sec}$. The third series was conducted to determine mosquito ability to pass through the $6 \mathrm{~mm}$ mesh net under a condition where the cages were completely coverd with a transparent plastic sheet, thus avoiding any influence of breeze. For comparison, partially covered cages were also tested, both ends of which were opened and air allowed to pass like a wind tunnel from the bait to the release cage. Then, in series 4, the passage rate at "without net" was also tested. In all these experiments, the analysis was made mainly on the "\% mosquitoes passing through the net," that is, it was based on the number recovered in the bait cage and the number engorged found in the release cage, or (No. recovered in bait cage + No. engorged found in release cage) / No. released.

\section{Results}

In all the experiments using the net, the rate of passage of oocyst-present mosquitoes in group A was always lower than that of oocyst-absent insects, regardless the size of mesh or whether covered by the plastic sheet. Out of 9 experiments, the difference in 4 of them was shown to be statistically significant. Even if no net was interposed the same results were obtained (Tables 1 and 2).

The difference of passage rate between oocyst-present and -absent mosquitoes was, however, not always extreme. In series 1, the cages were placed in side air-flow and the difference was remarkable. But in series 2 in the headwind position, the difference was almost negligible. To withdraw the wind factor, the cages were completely covered with a sheet and passage was studied in series 3 and 4 . The rate of oocyst-present mosquitoes in group $\mathrm{A}$ of the covered cages was then clearly lower than oocyst-absent ones. In contrast, oocyst-present mosquitoes in a partially covered condition in group $\mathrm{A}$ demonstrated slightly lower passage than the oocyst-absent ones, but there was no significant difference.

The effect of mesh size on \% passing varied. No clear tendency was observed among the different mesh sizes in series 1 and 2. Incidentally, the passage rate of oocyst-absent insects in group A did not greatly differ from group B. Higher rates were found in 5 experiments and lower rate in 4 experiments.

In series 3 and 4 , the effect of complete 
Table 1 Rate of passage through the net: Summary of 3 replications of each experiment of series 1 and 2. Mosquitoes in series 1 were exposed to a side air-flow and series 2 to a headwind. Groups A and B were fed simultaneously on an infected mouse and non-infected mouse, respectively.

\begin{tabular}{|c|c|c|c|c|c|}
\hline \multirow{2}{*}{\multicolumn{3}{|c|}{ Series }} & \multicolumn{2}{|c|}{ Group A $(\%)$} & \multirow{3}{*}{$\frac{\text { Group B (\%) }}{56.6}$} \\
\hline & & & \multirow{2}{*}{$\frac{\text { Oocyst }(+)}{20.0^{*, * *}}$} & \multirow{2}{*}{$\frac{\text { Oocyst }(-)}{54.5^{* *}}$} & \\
\hline 1. & With & $6 \mathrm{~mm}$ net & & & \\
\hline & & $8 \mathrm{~mm} \mathrm{net}$ & $10.3^{*, * *}$ & $57.1^{* *}$ & 66.9 \\
\hline & Withe & ut net & 74.2 & 100 & 80.6 \\
\hline \multirow[t]{4}{*}{2.} & With & $6 \mathrm{~mm}$ net & 65.2 & 78.9 & 41.6 \\
\hline & & $8 \mathrm{~mm}$ net & 80.6 & 87.5 & 68.5 \\
\hline & & $11 \mathrm{~mm}$ net & 81.8 & 90.0 & 51.8 \\
\hline & Witho & ut net & 80.0 & 92.8 & 71.8 \\
\hline
\end{tabular}

* Significant difference at $5 \%$ level from oocyst-absent mosquitoes. ** Significant difference at $5 \%$ level from "without net."

Table 2 Rate of passage through the net: Summary of 4 replications of each experiment of two batches of mosquitoes, series 3 and 4 . Groups A and B were fed simultaneously on an infected and non-infected mouse, respectively.

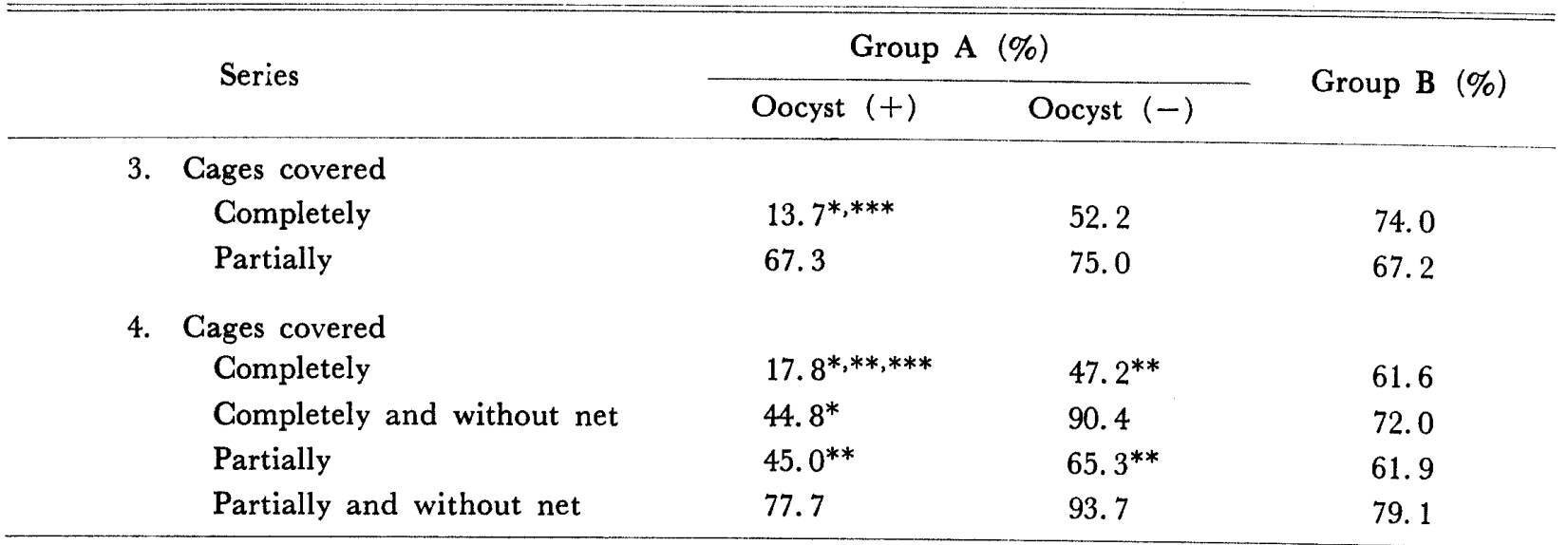

* Significant difference from oocyst-absent. ** Significant difference from "without net."

*** Significant difference from partially covered.

cover and partial cover was compared. Oocyst-present mosquitoes showed significantly lower passing rate at complete cover, but oocyst-absent insects showed no significant difference between complete and partial. When the net was removed the passage rate of mosquitoes increased greatly, both in oocyst-present and -absent in series 1 and 4, but in series 2 no clear difference was observed. Through all these series the rise in passing rate caused by removal of the net was much prominent in oocyst-present mosquitoes than -absent ones but the rate did not attain the level of non-infected insects (Tables 1 and 2).

Comparison was also done among the group A mosquitoes, those successful in passing the net $v s$. others which failed to pass. The rate of oocyst-present mosquitoes succeeding in passing was much lower than those failing in the 9 experiments. Geometric mean number of oocysts in the former mosquitoes was also much less than in the latter with one exception (Table 3 ).

Rate of blood feeding in each experiment was calculated based on the number of mos- 
Table 3 Geometric mean numbers of oocysts $(m)$ and \% oocyst-present mosquitoes in those fed on an infected mouse (=group A), calculated for mosquitoes passing through the net and those failing to pass through.

\begin{tabular}{|c|c|c|c|c|c|}
\hline \multirow{2}{*}{\multicolumn{2}{|c|}{ Series }} & \multicolumn{2}{|c|}{ Succeeded to pass } & \multicolumn{2}{|c|}{ Failed to pass } \\
\hline & & $m$ & $\%$ oocyst $(+)$ & $m$ & $\%$ oocyst $(+)$ \\
\hline \multirow[t]{3}{*}{1.} & With $6 \mathrm{~mm}$ net & 1.22 & $33.3^{*}$ & 7.18 & 70.5 \\
\hline & $8 \mathrm{~mm}$ net & 1.00 & $42.8^{*}$ & 10.61 & 89.6 \\
\hline & Without net & 5.51 & 76.4 & 44.18 & 100 \\
\hline \multirow[t]{4}{*}{2} & With $6 \mathrm{~mm}$ net & 1.16 & 50.0 & 3.43 & 66.6 \\
\hline & $8 \mathrm{~mm}$ net & 4.50 & 64.1 & 21.38 & 75.0 \\
\hline & $11 \mathrm{~mm}$ net & 6.09 & 75.0 & 4.49 & 85.7 \\
\hline & Without net & 1.33 & 44.4 & 1.62 & 50.0 \\
\hline \multirow[t]{2}{*}{3.} & Complete cover & 0.32 & $14.8^{*}$ & 1.64 & 54.3 \\
\hline & Partial cover & 4.50 & 67.3 & 10.95 & 75.0 \\
\hline \multirow[t]{4}{*}{4.} & Complete cover & 0.45 & $16.1^{*}$ & 0.99 & 44.2 \\
\hline & Complete and without net & 1.32 & $40.6^{*}$ & 33.27 & 88.8 \\
\hline & Partial cover & 0.55 & 21.4 & 1.41 & 40.7 \\
\hline & Partial and without net & 7.79 & 77.8 & 7.89 & 85.7 \\
\hline
\end{tabular}

* Significant difference from "failing to pass."

Table 4 Rate of blood feeding based on the number of mosquitoes entering the bait cage in each experiment. Groups A and B were fed simultaneously on an infected and non-infected mouse, respectively.

\begin{tabular}{|c|c|c|c|c|}
\hline \multirow{2}{*}{\multicolumn{2}{|c|}{ Series }} & \multicolumn{2}{|c|}{ Group A $(\%)$} & \multirow{2}{*}{ Group B $(\%)$} \\
\hline & & Oocyst $(+)$ & Oocyst $(-)$ & \\
\hline \multirow[t]{3}{*}{1.} & With $6 \mathrm{~mm}$ net & 100 & 100 & 52.9 \\
\hline & $8 \mathrm{~mm}$ net & 66.6 & 75.0 & 37.5 \\
\hline & Without net & 50.0 & 62.5 & 72.0 \\
\hline \multirow[t]{4}{*}{2.} & With $6 \mathrm{~mm} \mathrm{net}$ & 53.3 & 80.0 & 85.0 \\
\hline & $8 \mathrm{~mm}$ net & 84.0 & 71.4 & 67.5 \\
\hline & $11 \mathrm{~mm}$ net & 77.7 & 44.4 & 60.7 \\
\hline & Without net & 75.0 & 84.6 & 60.7 \\
\hline \multirow[t]{2}{*}{3.} & Complete cover & 50.0 & 30.4 & 80.0 \\
\hline & Partial cover & 54.8 & 40.0 & 59.4 \\
\hline \multirow[t]{4}{*}{4.} & Complete cover & 40.0 & 100 & 90.5 \\
\hline & Complete and without net & 61.5 & 73.5 & 61.1 \\
\hline & Partial cover & 66.6 & 93.9 & 90.9 \\
\hline & Partial and without net & 71.4 & 86.6 & 79.1 \\
\hline
\end{tabular}

quitoes entering the bait cage (=passing the net barrier) (Table 4). The comparison was being made in the oocyst-present vs. -absent insects of group A. Among the 9 experiments using the net, a higher feeding rate in oocystpresent was observed in 4 experiments, a lower rate in 4 experiments and the same rate in 1 . It seems that the infected mosquitoes, which succeeded to pass, have similar ability to feed on blood as the uninfected ones. Non was any clear difference found in the rate of group B mosquitoes and in the rate "without net" interposed. 


\section{Discussion}

The present experiments demonstrated that malaria-infected mosquitoes were impaired in their ability to access a blood source. Many of these mosquitoes were unable to pass through the net barrier, unlike healthy mosquitoes. This phenomenon was also supported by the fact that the mosquitoes successfully passing through the net had a lower density of oocysts than those failing to get through. Mosquitoes passing through were mainly oocyst-absent ones and those failing to pass were usually oocyst-present. It is suspected that the malaria parasite destroys some part of the normal mechanism functioning to guide the approach to a host.

How the parasite interferes with the mosquito's host-finding activity is of interest. From the present observations we can state that infected mosquitoes were as aggressive in feeding on blood as uninfected ones, as determined by the rate of those successful in entering the bait cage.

We may thus assume that various processes occur on arrival in the vicinity of a source for those mosquitoes aggressively wanting to feed. In small laboratory experiments, however, the process may differ somewhat compared with that in nature (Gillies, 1980). But even in a cage-test, mosquitoes must locate the blood source, and then must move toward it. To detect the source, night-feeding mosquitoes should be stimulated by airborne chemicals which emanate from the host body.

It was clear that oocyst-present mosquitoes were not as active as oocyst-absent ones and the non-infected B group, particularly under the conditions of less movement of air. Even if the net barrier was removed and a way to access the blood source fully opened, their passage rate did not attain the level of noninfected insects when cages were completely covered. Infected mosquitoes, it seems, were unable to activate the sensor to detect the blood source due to there being less movement of air. The rate was also remarkably lower than when cages were only partially covered. Consequently, it appeared as though they were not much concerned about a blood source even though it was located in an easily accessible spot. In contrast, in the case of a partially covered cage $77.7 \%$ of infected mosquitoes reached the nearby blood source. Does a certain receptor in a mosquito infected with a malaria parasite curtail the host-finding function in some way, particularly under a windless condition?

The impairment of kinetic functioning was also doubted as a mechanism of deterioration by a parasite. The passage rate of infected mosquitoes when the net was removed was higher but this increase phenomenon also happened in the uninfected mosquitoes. Thus the blockage of movement by the net was seen in both oocyst-present and -absent mosquitoes. It was reported earlier that mosquitoes could easily fly through the net if the mesh size was large enough. With smaller mesh size, a more complicated activity was necessary for the mosquitoes: they rested on the net for an average of $23 \mathrm{sec}$ and then walked through it (Itoh et al., 1986). This is a kinetic handicap not only for damaged but also for healthy mosquitoes, too. Therefore, at the present stage kinetic deterioration was not well demonstrated.

However, the rise in passing rate when the net was removed was somewhat more prominent in oocyst-present mosquitoes than in -absent ones. Therefore, it is suspected that the kinetic damage may not have occurred so conspicuously in the infected population. Reduced flight capability by parasitization with Plasmodium was demonstrated by Rowland and Boersma (1988) and by Schiefer et al. (1977). They explained that infected mosquitoes had reduced flight capability such as distance and duration. The equipment used in the present cage-test may well have been too small in size to evaluate their kinetic function.

In any event, the existence of less active insects due to parasitization is significant epidemiologically. The reduced ability of mosquitoes after becoming infected means limitation to their natural transmission activity. If such reduction occurs in nature, modified frequencies of biting and transmission may have important epidemiological implications. It is possible these mosquitoes will hesitate to enter a tear in a mosquito net (=bed-net) or a crack in the wall. This reaction enhances the effect of the wide mesh 
net-curtain method impregnated with insecticide. It was previously demonstrated by Kurihara et al. (1986) that the net curtain reduced the number of mosquitoes reaching the blood source. Even after reduction of the insecticidal effect a certain level of protection from infected mosquitoes is expected.

Incidentally, a similar passage rate of oocyst-present mosquitoes to noninfected mosquitoes was observed in a part of series 2 and 3. It is, therefore, possible to create a certain wind condition which may induce inversely exciting the infected mosquitoes.

It is still not clear whether the reduction in passage rate is attributable to the growth stage of the oocysts: ookinate development, epithelial damage, growing oocysts and sporozoite migration (Maier et al., 1987). We found that some mice bitten by group A mosquitoes in the present experiments showed parasitaemia soon after the cage tests; thus we cannot overlook any possibility. Our studies are continuing.

\section{REFERENCES}

Gad, A. M., W. A. Maier and G. Piekarski (1979): Pathology of Anopheles stephensi after infection with Plasmodium berghei berghei. Z. Parasitenkunde, 60: 249-261.

Gillies, M. T. (1980): The role of carbon dioxide in host-finding by mosquitoes (Diptera; Culicidae): A review. Bull. Entomol. Res., 70: 525532 .

Ichimori, K. (1989) : Correlation of mosquito size, blood meal size and malarial oocyst production. Jpn. J. Sanit. Zool., 40: 81-85.

Itoh, T., G. Shinjo and T. Kurihara (1986): Studies on wide mesh netting impregnated with insecticides against Culex mosquitoes. J. Am. Mosq. Control Assoc., 2: 503-506.

Klein, T. A., B. A. Harrison, R. G. Andre, R. E. Whitmire and I. Inlao (1982): Deterimental effects of Plasmodium cynomolgi infections on the longevity of Anopheles dirus. Mosq. News, 42: 265-271.

Klein, T. A., B. A. Harrison, J. S. Grove, S. V. Dixon and R. G. Andre (1986): Correlation of survival rates of Anopheles dirus A (Diptera: Culicidae) with different infection densities of Plasmodium cynomolgi. Bull. W.H.O., 64: 901907.

Kurihara, T., K. Fujita and T. Suzuki (1985) : Insecticide treatment of wide-mesh net curtain for vector control and the effect upon behaviour responses of adult mosquitoes. Jpn. J. Sanit. Zool., 36: 25-30 (in Japanese).
Kurihara, T., K. Ichimori, C. F. Curtis and M. I. Hossain (1989): Behavioural studies in the laboratory. In: Appropriate Technology in Vector Control (ed., Curtis, C. F.), pp. 16-23, CRC Press, Boca Raton, Florida.

Kurihara, T., K. Kamimura and R. Arakawa (1986) : Phenothrin impregnation of wide-mesh net for protection from biting mosquitoes. $J p n$. J. Sanit. Zool., 37: 261-262.

Kurihara, T. and T. Umino (1987): The effects of insecticides on the behaviour of female mosquitoes under the laboratory conditions. Jpn. J. Sanit. Zool., 38: 25-32 (in Japanese with English summary).

Maier, W. A., H. Becker-Feldman and H. M. Seitz (1987): Pathology of malaria-infected mosquitoes. Parasitol. Today, 3: 216-218.

Rossignol, P. A., J. M. C. Ribeiro and A. Spielman (1984): Increased intradermal probing time in sporozoite-infected mosquitoes. Am. J. Trop. Med. Hyg., 33: 17-20.

Rossignol, P. A., J. M. C. Ribeiro and A. Spielman (1986): Increased biting rate and reduced fertility in sporozoite-infected mosquitoes. $\mathrm{Am} . \mathrm{J}$. Trop. Med. Hyg., 35: 277-279.

Rowland, M. and E. Boersma (1988): Changes in the spontaneous flight activity of the mosquito Anopheles stephensi by parasitization with the rodent malaria Plasmodium yoelii. Parasitology, 97: 221-227.

Schiefer, B. A., R. A. Ward and B. F. Eldridge (1977): Plasmodium cynomolgi; Effects of malaria infection on laboratory flight performance of Anopheles stephensi mosquitoes. Exp. Parasitol., 41 : 397-404.

\section{摘 要}

室内試験でみられた Plasmodium yoelii nigeriensis に感染された Anopheles stephensi の吸血源接近の行動

マラリア媒介蚊が病原体をとりこんだために，末感 染の蚊に比して, その寿命を短縮したり行動の束縛を らけたりすることは，少ないというのが従来の報告と しては多かった．近年この点についてネズミマラリア などを供しての実験で，いくつかの暴論がみられる. われわれは, An. stephensi にネズミマラリアの一種 P. yoelii nigeriensis を吸血によりとりこませた. そ の 5 日後に産卵させ，10日後にケージテスト法で，障 害物である網を越してベイトのマウスに接近し吸血す る状況を調べた，その結果オーシスト保有の蚊は，非 保有の蚊と比べて，網目サイズの大小にかかわらず， 網を越して接近する率が低いことを見いだした。とく にテストの装置をビニール布でおおって外気を遮断す ると， $6 \mathrm{~mm}$ メッシュの網を越える率が著しく低率に なることが明らかになった. 本原虫感染が媒介蚊の吸 血源感知の能力や接近飛翔に影響をむたらしていると 考えられる。 